\title{
Beilschmiedia berteroana (Gay) Kosterm (Lauraceae): A new population of importance for conservation and distribution in the Maule Region of Central Chile
}

\author{
Pablo Bravo-Monasterio ${ }^{1 *}$, Gonzalo Gallardo Ramírez ${ }^{2}$ and Gabriela Baeza Horta ${ }^{2}$ \\ 1 Universidad de Concepción, Facultad de Ciencias Forestales, Laboratorio de Invasiones Biológicas (LIB). Casilla 160-C, Barrio Universitario. ZIP \\ Code: 4121639. Concepción, Chile \\ 2 CARILEMU, Programa de Ecología y Biodiversidad, Unidad de Proyectos de Conservación y Educación Ambiental. Avenida Lircay s/n. Universidad \\ de Talca. ZIP Code: 3465548. Talca, Chile. \\ * Corresponding author. E-mail: pbravom@udec.cl
}

\begin{abstract}
This study reports the location of new populations of Beilschmiedia berteroana (Gay) Kosterm in Achibueno, 32 $\mathrm{km}$ to southeast of the city of Linares, Maule Region, central Chile. This finding is of utmost importance for the conservation of $B$. berteroana on account of its mass disappearance stemming from the clear cutting and construction of a dam on the Ancoa river in the Maule region. During the months of March to December of 2011 we sampled a population with 25 adult individuals dispersed in approximately $10000 \mathrm{~m} 2$ located $40 \mathrm{~km}$ to the south of the previously known population in the Bellotos del Melado National Reserve. It is recommended that support be given to new scientific research and work for conservation this species.
\end{abstract}

Beilschmiedia berteroana is an endemic tree in Chile which forms shadowy woods with a humid-cold interior microclimate with an absence of herbaceous strata and soil covered by abundant leaf litter. Trees can reach a height of $30 \mathrm{~m}$ and an average diameter of $27 \mathrm{~cm}$, have aromatic leaves and fruit consists of berries (San Martín et al. 2002). Due to their likeness to fruits of the genus Quercus, they are called "bellotas" (acorns) and are consumed by swine and occasionally cattle (San Martín et al. 2002). Their natural distribution extends from the northern portion of the Province of Melipilla, Metropolitan Regional (Roblería del Cobre de Loncha National Reserve and its surrounding area between $70^{\circ} 55^{\prime}-71^{\circ} 12^{\prime} \mathrm{W}, 34^{\circ} 03^{\prime}-34^{\circ} 11^{\prime} \mathrm{S}$ to the Larqui River in the Bio-Bio Region, at $36^{\circ} 43^{\prime} \mathrm{S}, 72^{\circ} 11^{\prime} \mathrm{W}$; Hechenleitner et al. 2005; Ricci et al. 2007), with the largest representation of specimens in the foothills and valleys of the Maule Region (Rodríguez et al.1983; Rodríguez and Quezada 2001).

This tree is highly threatened and is thought to have had a much larger distribution in the past. In the present it has been greatly reduced by the effects of fire, grazing and the transformation of native woods into forestry plantations (Hechenleitner et al. 2005). It is protected in the Bellotos del Melao National Reserve (Litton et al. 1997) and Roblería del Cobre de Loncha National Reserve, the latter being the only protected site of the sole southern "Belloto" population in the coastal foothills (Ricci et al. 2007).

The reduced distribution of $B$. berteroana can be attributed to the constant changes in soil for use in agriculture and forestry as this species is of no commercial lumber value nor of use as firewood (San Martin et al. 2002). On account of these conditions, this species is declared to be in danger of extinction (Benoit 1989; IUCN 2001).
The "Belloto" populations found in the Maule Region fall under a scenario which, from the perspective of conservation biology, find themselves in one of the areas whose biodiversity is under greatest threat due to the existence of a large number of flora species in the categories of "In danger of extinction", "Vulnerable" and "Rare" (Olivares et al. 2005). It is calculated that only $0.6 \%$ of the regional territory is protected by the Chilean State under the System of Protected Areas (SNAPSE) and this area also forms a portion of one of the 34 Global conservation and biodiversity Hotspots (Olivares et al. 2005).

In the Maule Region there are five priority sites for the conservation of biodiversity, which are outlined under the national strategy for conservation and biodiversity (CONAMA 2003). Data collection and flower surveys were undertaken in Altos de Achibueno, located $33 \mathrm{~km}$ to the southwest of the city of Linares, in the foothills of the

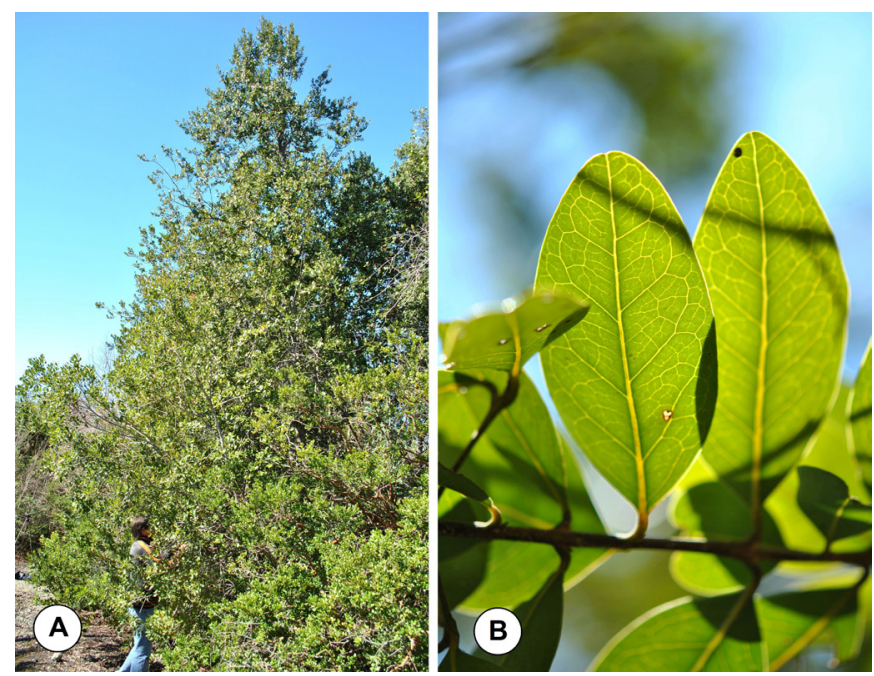

FIGURE 1. Mixed Wood with presence of individuals of Beilschmiedia berteroana (Gay) Kosterm. A) Adult individual. B) Detail of the leaves. 
Maule Region (MMA-FPA project - 07-042-2011), with the resulting discovery of a small population of "Belloto del Sur" Beilschmiedia berteroana (Gay) Kosterm. (Fig. 1A and B) located specifically at $36^{\circ} 09^{\prime} 31^{\prime \prime} \mathrm{S}, 71^{\circ} 18^{\prime} 29.13^{\prime \prime} \mathrm{W}$, in the area known as "Vado Azul" (Figure 2). During the months of March to December of 2011 we sampled a population with 25 adult individuals dispersed in approximately $10000 \mathrm{~m}^{2}$ in Altos de Achibueno and $40 \mathrm{~km}$ to the south of the previously known population in the Bellotos del Melado National Reserve. The collected material was deposited in the herbarium of the Department of Botany of the University of Concepción under number 175237.

This finding is of utmost importance to the conservation of the species, on account of its mass disappearance stemming from the clear cutting and posterior construction of a dam on the Ancoa river, for which it is estimated that 1200 individuals were cut (José San Martin and Cristian Alegría, personal communication) from one of the Maule Region largest populations located in the vicinity of Bellotos del Melado National Reserve. Despite its status as a protected species, cutting was authorized under supreme decree 654 of 2009 , which has since been overturned.

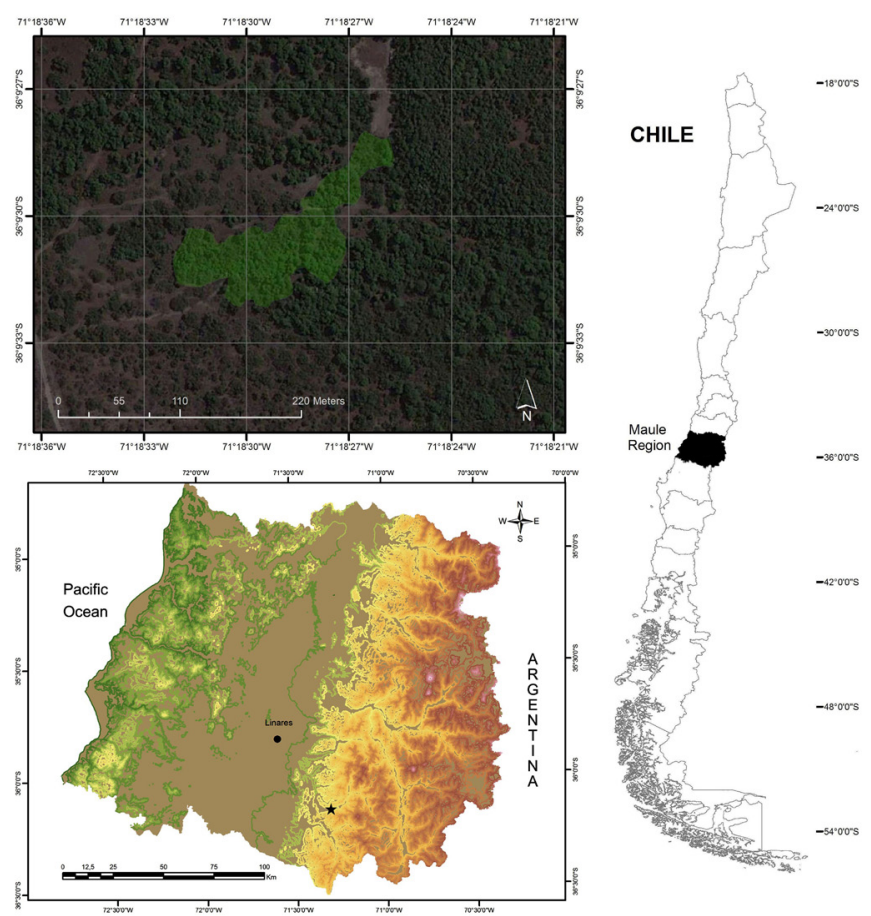

FIGURE 2. New population of Beilschmiedia berteroana (Gay) Kosterm in Altos Achibueno, located in central Chile in the Maule Region.
The new finding in Altos de Achibueno presents new threats owing to the historic loss of biodiversity due to the substitution or loss of native forest, a phenomena which has been studied by Altamirano and Lara (2010), who mention that, in intermediate parts of Andes mountain in the Maule region between 1989 and 2003, the native forest in this zone was reduced by $44 \%$. Furthermore, a large proportion of current exotic plantations are established on soils that previously corresponded to native forest (67\%). It is recommended that support be given to new scientific research and work for conservation this species.

ACKNOWLEDGMENTS: The authors thank FPA Project 07-042-2011 of the Ministry of the Environment of Chile and Mr. Eduardo Ibáñez, who provided the information necessary for the discovery in this locality, as well as his kind companionship during field studies.

\section{LITERATURE CITED}

Altamirano A. and A. Lara. 2010. Deforestación en ecosistemas templados de la precordillera andina del Centro-Sur de Chile. Revista bosque 31(1): 53-64.

Benoit, I. 1989. Red book of Chilean Terrestrial Flora. Santiago: Corporación Nacional Forestal (CONAF). 151 p.

CONAMA. 2003. Estrategia nacional de biodiversidad. Santiago: CONAMA. $21 \mathrm{p}$.

Hechenleitner, P., M. Gardner, P. Thomas, C. Echeverría, B. Escobar, P. Brownless and C. Martínez. 2005. Plantas Amenazadas del Centro - Sur de Chile. Valdivia: Universidad Austral de Chile y Real Jardín Botánico de Edimburgo (UK). 187 p.

IUCN 2001. Red List Categories and Criteria: Version 3.1. Gland: IUCN. 33p.

Litton, C., J. Díaz and R. Lara. 1997. Composición florística y estructura vertical de un rodal de Beilschmiedia berteroana (Gay) Kosterm. en la precordillera andina de la VII Región de Chile. Revista bosque 18(1): 61-72.

Olivares, P., J. San Martín and R. Santelices. 2005. Ruil: Estado del conocimiento y desafíos para su conservación. Talca: Departamento de protección de recursos naturales, Comisión Nacional del Medio Ambiente, Región del Maule, Chile. 56 p.

Ricci, M., H. González, R. Cerda, A. Aguilar and O. Celis. 2007. Ampliación del límite norte de distribución del Belloto del Sur (Beilschmiedia berteroana, Lauraceae). Chloris Chilensis 2(2). Electronic Database accessible at http://www.chlorischile.cl/. Captured on 20 August 2011.

Rodríguez, R. and M. Quezada. 2001. Laurales; p. 10-19 In C. Marticorena and R. Rodríguez (ed.). Flora de Chile. Concepción: Ediciones de la Universidad de Concepción.

Rodríguez, R., M. Quezada and O. Matthei. 1983. Llora Arbórea de Chile. Concepción: Ediciones de la Universidad de Concepción. 360 p.

San Martin, J., A. Villa and C. Ramírez. 2002. Fenología y crecimiento vegetativo de Beilschmiedia berteroana (Gay) Kosterm. en la

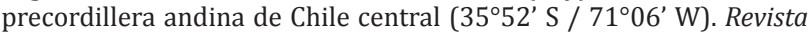
Bosque 23(1): 37-45.

RECEIVED: October 2011

ACCEPTED: June 2012

PublishED ONLINE: August 2012

EDITORIAL RESPONSIBILITY: Pedro V. Eisenlohr 